\title{
Toxic effect of copper on marine picophytoplankton populations isolated from different geographic locations
}

\author{
BIBIANA DEBELIUS ${ }^{1}$, JESÚS M. FORJA ${ }^{1}$, ÁNGEL DELVALLS ${ }^{1}$ \\ and LUIS M. LUBIÁN ${ }^{2}$ \\ ${ }^{1}$ Dpto. Química-Física, Universidad de Ciencias del Mar y Ambientales, Avda. República Saharaui, s/n, \\ 11510, Puerto Real, Cádiz, Spain. E-mail address: bibiana.debelius@uca.es \\ 2 Instituto de Ciencias Marinas de Andalucía, CSIC, Avda República Saharaui, 2, 11510, Puerto Real, Cádiz, Spain. \\ Associated Unit of Interdisciplinary Oceanography (CSIC and UCA).
}

\begin{abstract}
SUMMARY: In an approach to understand more about copper toxicity effects on marine microalgae, 72-h growth inhibition toxicity tests were followed on natural picophytoplanktonic populations belonging to different coastal and oceanic geographic locations (Mediterranean Sea and Atlantic Ocean) covering, at an approximate longitude of $30^{\circ} \mathrm{W}$, latitudes from $32^{\circ} 14^{\prime} \mathrm{S}$ to $29^{\circ} 10^{\prime} \mathrm{N}$. Analyses of samples established different predominant populations for different locations. Copper toxicity tests showed a group of cyanobacteria isolated from coastal samples that were the most sensitive, and a second group of picoeukaryotes collected from the Atlantic Ocean surface, which were more tolerant to copper. The use of flow cytometry for studying copper toxic effects provided a variety of information on cell parameters in addition to cellular density. In particular, an established increase in copper tolerance with increase of cell size was observed in cyanobacteria, but it was not clearly followed in picoeukaryotes. This study aims to relate copper tolerance to the geographic location sites of sampling collection. The results obtained establish that other factors such as cell size, proximity to the coast and copper concentration in situ are considered to have a greater influence than the fact of belonging to a determined location site.
\end{abstract}

Keywords: natural picoplankton populations, geographic distribution, copper, toxicity, cyanobacteria, picoeukaryotes.

RESUMEN: EFECTO TÓXICO DEL COBRE EN POBLACIONES NATURALES DE PICOPLANCTON AISLADAS, PROCEDENTES DE DISTINTAS LOCALIZACIONES GEOGRÁFICAS. - Con el fin de estudiar el efecto tóxico del cobre en las microalgas marinas, se llevaron a cabo ensayos de toxicidad $(72 \mathrm{~h})$ con poblaciones naturales de picofitoplancton. Poblaciones procedentes de distintas localizaciones geográficas (mar Mediterráneo y océano Atlántico), cubriendo, aproximadamente en la longitud de $30^{\circ} \mathrm{O}$, latitudes comprendidas entre $32^{\circ} 14^{\prime} \mathrm{S}$ y $29^{\circ} 10^{\prime} \mathrm{N}$. El análisis inicial de las muestras permitió distinguir las poblaciones predominantes de cada estación de muestreo, a exponer en los ensayos de toxicidad. En resumen, un grupo de cianobacterias procedentes de las muestras costeras resultaron ser las más sensibles, y un segundo grupo de picoeucariotas, tomadas de la superficie del océano Atlántico, las más tolerantes al cobre. El análisis del ensayo se llevó a cabo mediante citometría de flujo lo que permitió estudiar otros parámetros celulares, aparte de la densidad celular. Pudiendo observar, en el caso de las cianobacterias, un incremento de la tolerancia al cobre con incremento de su tamaño celular; que no resultó tan evidente en el caso del grupo de picoeucariotas. Finalmente, al relacionar la tolerancia al cobre con las poblaciones procedentes de distintas localizaciones geográficas de muestreo podemos concluir que, otros factores, tales como: el tamaño celular, proximidad a costa, o concentraciones del metal in situ, pueden tener una mayor influencia que la localización geográfica de la población.

Palabras clave: poblaciones naturales de picoplancton, distribución geográfica, cobre, toxicidad, cianobacterias, picoeucariotas.

\section{INTRODUCTION}

Copper is essential in trace amounts, but becomes toxic when exposed to higher concentrations than is physiologically necessary. Trace metals exist at nanomolar and picomolar concentrations in seawater (Bruland and Franks, 1983), which are orders of magnitude below the concentrations found in terrestrial 
ecosystems. They can have either a positive or negative effect on phytoplankton productivity and species distributions in oceans (Coale, 1991). For hundreds of years there has been an increase in dissolved copper concentrations, especially those found in coastal systems, as a result of anthropogenic inputs. This is the case even in remote environments: Hong et al. (1996) establish that the atmospheric flux of copper to Greenland ice has increased by more than one order of magnitude from the pre-Roman period to the present.

A great deal of information is available on the effects of copper toxicity on freshwater and marine microalgae from isolated culture collections, but little on its effects on recently collected microalgae populations (Wolter et al., 1984; Mann et al, 2002; Le Jeune et al, 2006). The study of these effects on the complexity of the aquatic environments is an important objective in ecotoxicology, due to the possible differences between the sensitivity of laboratory species and that of field-collected species (Janseen et al., 2003).

It is reported that the sensitivity of phytoplankton to copper varies among algal species (Thomas and Seibert, 1977). Although there are exceptions, dinoflagellates and cyanophytes are more copper-sensitive groups, and green flagellates (Gustavson and Wänberg, 1995) and diatoms ( Stauber and Davis, 2000) are more resistant. Cyanobacteria are one of the most sensitive species to copper toxicity in the laboratory. Brand et al. (1986) suggest that this may be because their ancestors evolved in an anoxic environment where the bioavailable copper concentration was low. Their small size and high surface-to-volume ratio also make these organisms more vulnerable to potentially toxic copper concentrations. On the other hand, larger eukaryotic cells tend to be more resistant to copper toxicity.

This paper is intended to be a preliminary study in marine microalgae ecotoxicology. In future, more samples of natural picoplankton should be collected around the world and assayed. The aim of this study is, first, to establish the effects of copper on natural marine microalgae samples, including samples from coastal sites and from oceanic locations (cyanobacteria and photosynthetic picoeukaryotes) and, second, to determine whether there is any possible relationship of copper tolerance to microalgae geographic position, in addition to the already established differences between cyanobacteria and eukaryotes.

\section{MATERIALS AND METHODS}

\section{Sample locations and picophytoplankton populations}

The assays of copper toxicity effects were performed on picophytoplankton populations collected from 8 different geographic locations in the Mediterranean Sea and Atlantic Ocean (divided in coastal and oceanic samples). Figure 1 shows the location of coastal seawater samples corresponding to the Medi-

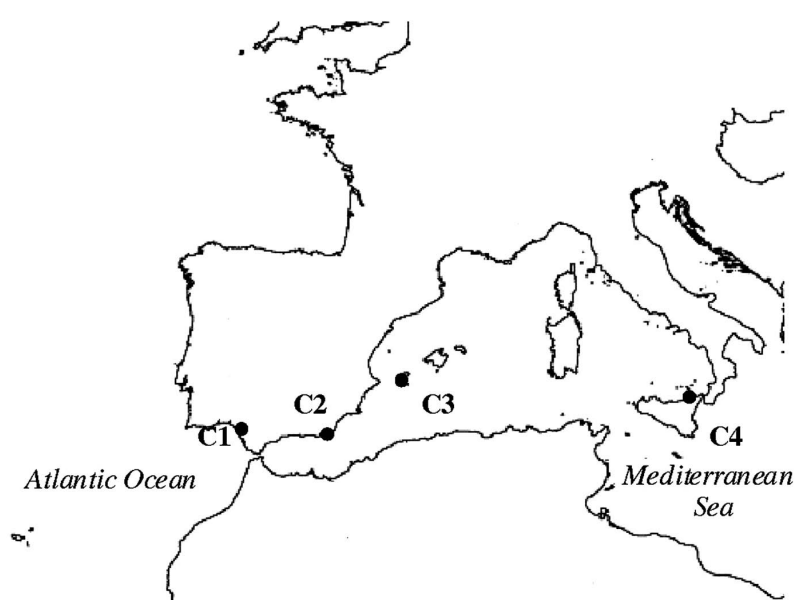

FIG. 1. - Geographic locations of coastal sampling stations.

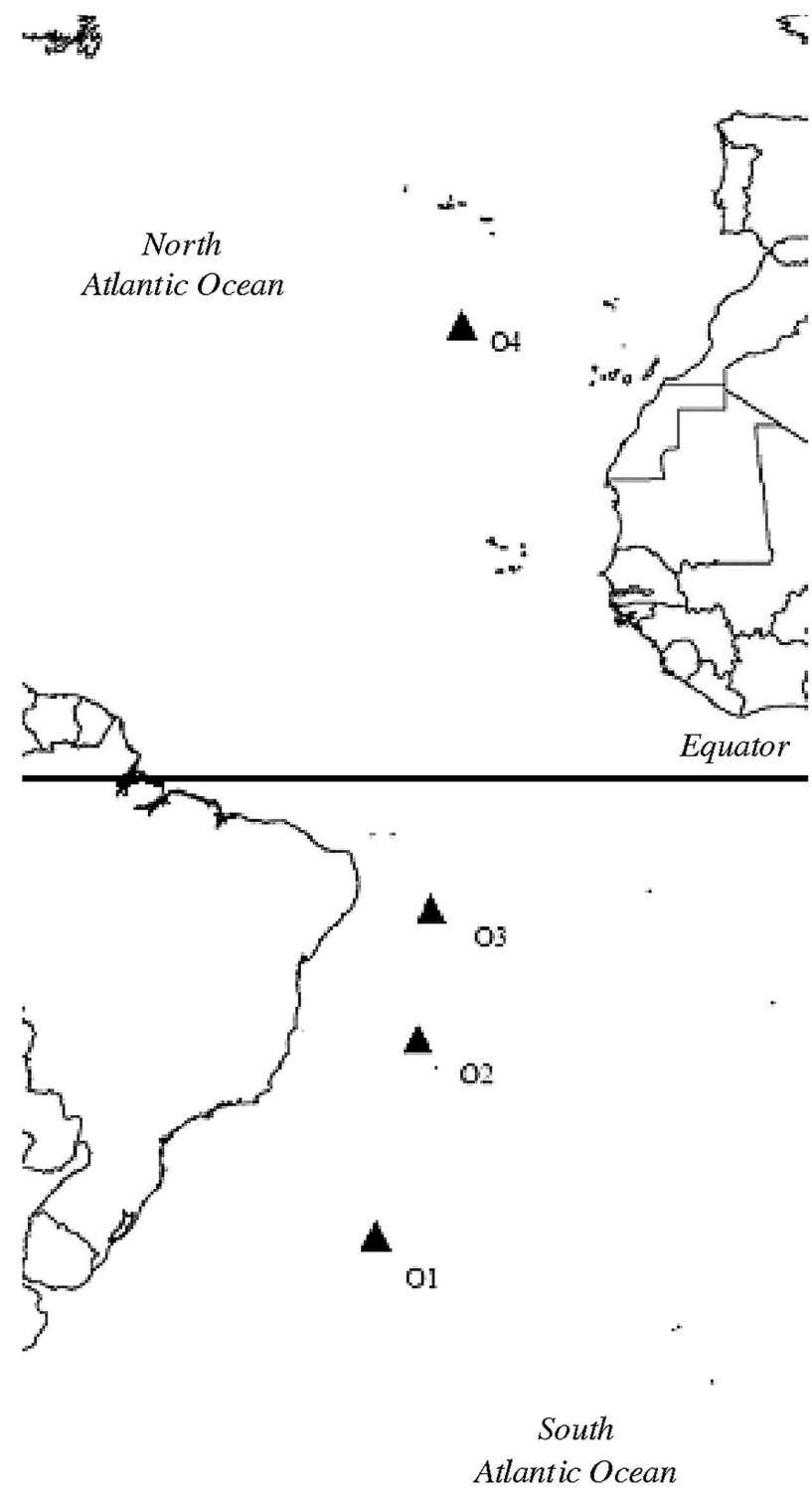

FIG. 2. - Geographic locations of oceanic sampling stations. 
TABLE 1. - Geographic locations and cytometric data of the eight samples exposed to toxicity assays with copper (coastal samples C1-C4, oceanic samples O1-O4). Subscript "a" on SSC (sidescatter, cell size), FL3 (chlorophyll $a$ autofluorescence), FL4 (phycocyanin), and FL2 (phycoerythrin), indicates data corresponding to average arbitrary units.

\begin{tabular}{lccccc}
\hline Samples & Goegraphic Loc. & SSC $_{\mathrm{a}}$ & FL3 $_{\mathrm{a}}$ & $\mathrm{FL4}_{\mathrm{a}}$ & $\mathrm{FL}_{\mathrm{a}}$ \\
\hline $\mathrm{C} 1$ & $36^{\circ} 54^{\prime} \mathrm{N} 6^{\circ} 17^{\prime} \mathrm{W}$ & 230 & 574 & 380 & \\
$\mathrm{C} 2$ & $36^{\circ} 45^{\prime} \mathrm{N} 2^{\circ} 12^{\prime} \mathrm{W}$ & 2150 & 4652 & 3080 & \\
$\mathrm{C} 3$ & $39^{\circ} 0^{\prime} \mathrm{N} 1^{\circ} 39^{\prime} \mathrm{E}$ & 49 & 116 & 211 & \\
$\mathrm{C} 4$ & $38^{\circ} 11^{\prime} \mathrm{N} 15^{\circ} 5^{\prime} \mathrm{E}$ & 84 & 173 & 310 & \\
$\mathrm{O} 1$ & $32^{\circ} 24^{\prime} \mathrm{S} 33^{\circ} 31^{\prime} \mathrm{W}$ & 127 & 2174 & & \\
$\mathrm{O} 2$ & $20^{\circ} 19^{\prime} \mathrm{S} 29^{\circ} 7^{\prime} \mathrm{W}$ & 58 & 944 & & \\
O3 & $9^{\circ} 5^{\prime} \mathrm{S} 28^{\circ} 59^{\prime} \mathrm{W}$ & 52 & 52 & & 69 \\
O4 & $29^{\circ} 10^{\prime} \mathrm{N} 28^{\circ} 56^{\prime} \mathrm{W}$ & $58 / 8$ & $1760 / 245$ & & 69 \\
\hline
\end{tabular}

terranean Sea (three sites) and the Atlantic Ocean (one site). Figure 2 shows the location of the other four sites, corresponding to oceanic samples. The latter were obtained during an oceanographic cruise aboard the Spanish Oceanographic vessel Hesperides by means of an oceanographic rosette with coupled CTD. Samples collected from the Atlantic Ocean cover, at an approximate longitude of $30^{\circ} \mathrm{W}$, latitudes from $32^{\circ} 14^{\prime} \mathrm{S}$ to $29^{\circ} 10^{\prime} \mathrm{N}$. Table 1 includes the population nomenclature, exact geographic location and measured cytometric parameters.

Once collected, all samples were filtered with a 3 $\mu \mathrm{m}$ filter and natural communities of picoeukaryotes were kept in a culture chamber, previous to toxicity tests. Coastal samples were subjected to isolation (with agar plates) in order to obtain isolated populations of cyanobacteria. Then samples were maintained in $\mathrm{f} / 2$ culture medium inside a culture chamber at $25 \pm 0.4^{\circ} \mathrm{C}$ and a 12:12-h white light:dark photoperiod (32 $\mu \mathrm{mol}$ $\mathrm{m}^{-2} \mathrm{~s}^{-1}$ ) until the beginning of the toxicity test. Toxicity tests were started as soon as possible once the oceanographic cruises had ended (remaining no long than 30 days in chamber).

\section{Toxicity assays}

Before exposure to copper, all samples were analyzed by flow cytometry to distinguish the existing groups of populations, sizes, chlorophyll $a$ intensity, and phycobilins (included in Table 1). Moreover, by means of HPLC the pigmentary profile obtained showed that all coastal isolates were cyanobacteria (Synechococcus and Synechocystis) and that all oceanic isolates were chlorophyte algae (Nannochloris), except for the oceanic sample O4, which showed another population detected by flow cytometry with phycoerythrin signal. This population may correspond to the "marine Synechococcus" established by Waterbury et al. (1986), found in the euphotic zone of oceanic waters in the world's temperate and tropical oceans.

Seventy-two-hour toxicity tests were performed in two batches: coastal samples were exposed to lower copper concentrations (preliminary studies showed high sensitivity to copper; Debelius et al. 2009) of 0,
1.5, 3 and $9 \mu \mathrm{g} \mathrm{L} \mathrm{L}^{-1}$ and oceanic samples were exposed to higher copper concentrations of $0,3,9$ and $18 \mu \mathrm{g}$ $\mathrm{L}^{-1}$, all performed in triplicate. The different copper concentrations were added as diluted Merck standard solution; $\mathrm{pH}$ was measured at the beginning and end of the toxicity tests, with no variations being found (added acidified stock was less than $0.5 \%$ of the total volume). In addition, all samples were diluted to initial cellular densities close to natural conditions of $10^{3}-10^{4}$ cell $\mathrm{mL}^{-1}$; oceanic samples were diluted in Atlantic oceanic water brought from the oceanographic cruise. The medium was enriched with a final concentration composed of $\mathrm{NO}_{3}^{-}(123.88 \mu \mathrm{M})$ and $\mathrm{PO}_{4}^{3-}(4.01 \mu \mathrm{M})$. This medium was chosen rather than another standard enriched medium, such as Guillard's f/2 formulation, because it has been demonstrated that EDTA greatly decreases the toxicity of metals due to the chelating properties of the molecules (Sunda and Guillard, 1976; Moreno-Garrido, 1997).

Assays were performed in 50-mL Erlenmeyer flasks, previously cleaned with dilute nitric acid (10\%) and rinsed several times with Milli-Q water before experiments. Twenty-mL samples with each copper concentration but without microalgae were also added in the toxicity test to analyze, in situ, any copper concentrations in natural samples, adsorption to glass and real exposure to added copper concentrations. Toxicity tests were maintained in the same culture chamber, in the same conditions as when the samples reached the laboratory.

During all experiments the nominal $\mathrm{Cu}$ concentrations, including the control, were measured at the end of the toxicity tests using a Metrohm $663 \mathrm{VA}$ stand equipped with an $\mathrm{Hg}$ electrode, with $1 \mu \mathrm{g} \mathrm{\textrm {L } ^ { - 1 }}$ limit detection (DP-VRA). Solutions were purged with high purity nitrogen for $8 \mathrm{~min}$ before measurements. A deposition potential of $-1.1 \mathrm{~V}$ was applied for $300 \mathrm{~s}$, with stirring, followed by a non-stirring period of $10 \mathrm{~s}$. Potential was scanned at $13.3 \mathrm{mV} \mathrm{s}^{-1}$ at a pulse amplitude of $30 \mathrm{mV}$.

\section{Flow cytometric analysis}

Experimental samples were removed from the culture chamber after the 72-h copper exposure and were analyzed using a FACSCalibur flow cytometer (Becton-Dickinson) equipped with a blue argon-laser $(488 \mathrm{~nm})$, a red diode $(635 \mathrm{~nm})$ and a four-colour photomultiplier with fluorescence filters (FL1 515-545 nm, FL2 564-606 nm, FL3 >650 nm and FL4 653-669 $\mathrm{nm}$ ), forward light scatter (FSC) and side scatter (SSC). Data were computed with CellQuest software (Beckton-Dickinson). Each culture was analyzed for 30-60 s (6000 to 10000 events per measurement, at a flow rate previously calibrated by an established sample weight during a constant period of time) from samples $(20 \mathrm{~mL}$, not diluted) previously fixed with $3-4 \%$ formaldehyde. The reason for fixing the samples was the difference in time when measuring from the first to the last sam- 

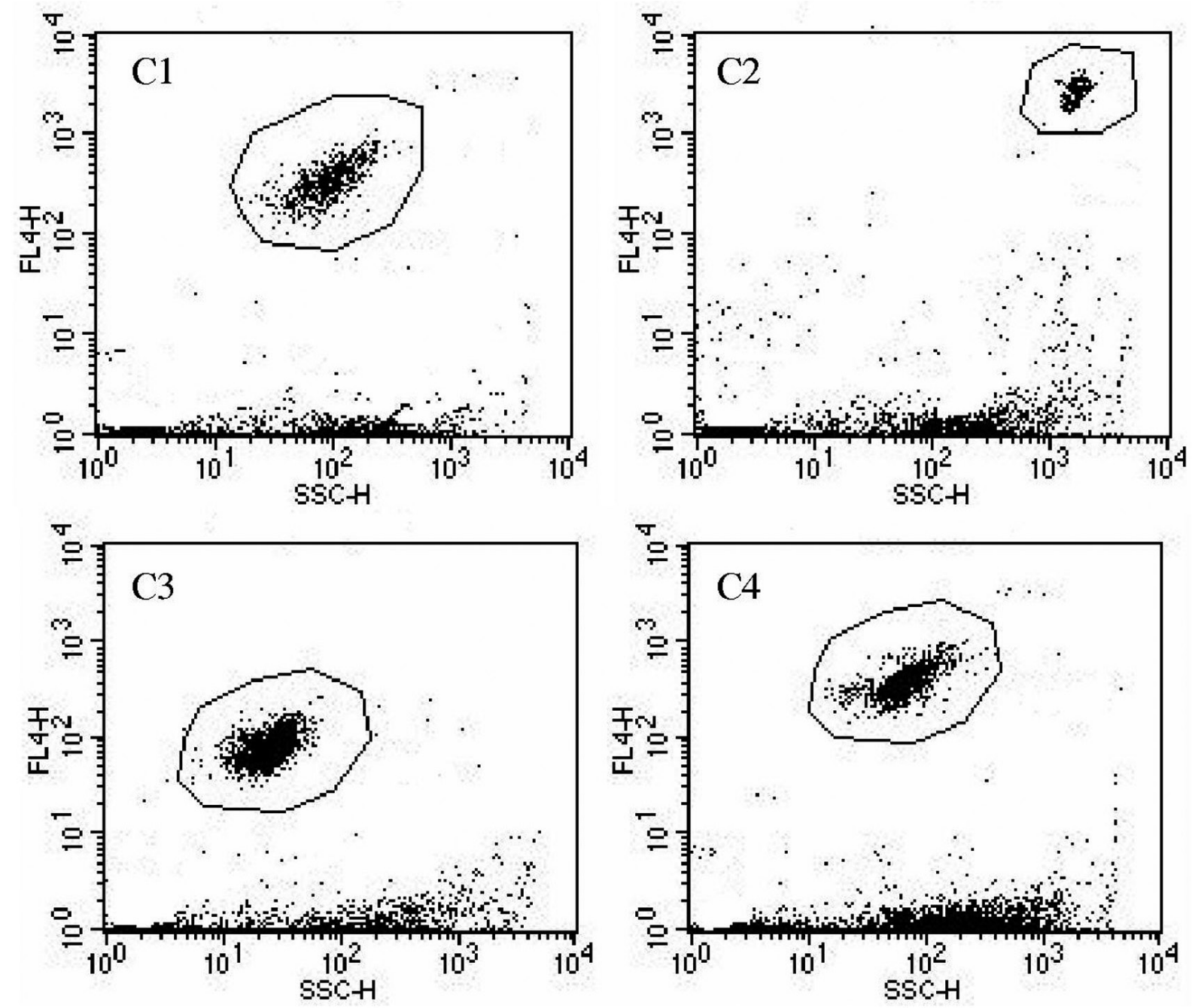

FIG. 3. - Flow cytometry dot plots of cell size vs phycocyanin signals of isolated coastal cyanobacteria population samples.

ple; this way all samples were measured at the same time (at hour 72). Counts, signals of SSC, chlorophyll $a$ autofluorescence (FL3) phycoerythrin (FL2) and phycocyanin (FL4) obtained as arbitrary units were recorded. The SSC signal was used as a cellular size indicator instead of FSC, since previous studies show that this signal has a better correlation with the cell size (Sobrino et al., 2005).

\section{Statistical analysis}

The 72-h $\mathrm{EC}_{50}$ values were obtained from the adjustment of growth inhibition data (in comparison with a growth control) to a sigmoid equation, corresponding to each contaminant and microalga.

\section{RESULTS}

\section{Flow cytometry data}

Before starting each of the toxicity tests, samples were analyzed by flow cytometry to determine the existing population's size, chlorophyll $a$ and pigment characteristics (included in Table 1). Populations belonging to coastal samples were delimited by representing data in the two-parameter SSC vs phycocyanin signal dotplots (Fig. 3), because they gave better results than SSC vs. FL3. The high signal of phycocyanin in the case of cyanobacteria allowed a better delimitation of populations than when the FL3 chlorophyll $a$ signal was used.

In the case of the other four oceanic samples, populations by flow cytometry were delimited by $\operatorname{SSC} v s$. FL3 dotplots, and in the case of the O4 sample, in which another population with a phycoerythrin signal was detected, by SSC vs. FL2 dotplots, as shown in Figure 4. Obtained data of initial and final cellular densities, for all populations studied, at the maximum copper concentration toxic effect are shown in Table 2.

\section{Toxicity assays}

Growth inhibition toxicity effects of copper were higher in coastal than in oceanic populations, showing 

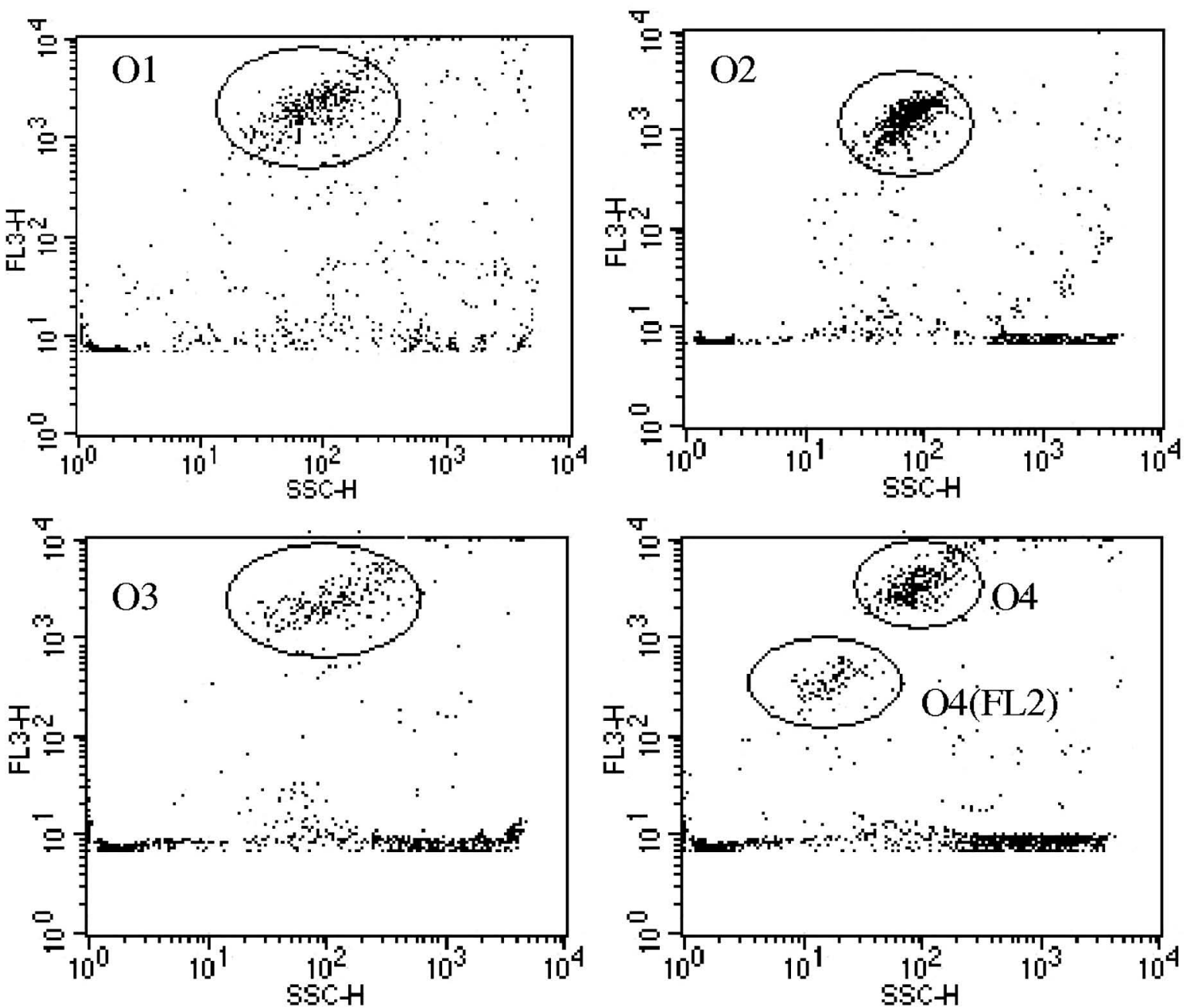

FIG. 4. - Flow cytometry dot plots of cell size vs chlorophyll $a$ signals of oceanic picoeukaryotes (O1, O2, O3, O4) and O4(FL2) cyanobacteria population.

that the coastal cyanobacteria had a higher sensitivity to copper than the picoeukaryotes from the Atlantic Ocean. Measured copper control concentrations for coastal and oceanic seawater showed values below the detection limit of differential pulse voltammetry (DP-VRA) $\left(<1 \mu \mathrm{g} \mathrm{L}^{-1}\right)$, although coastal samples

TABLE 2. - Initial and final cell densities $\left(\right.$ cell $\left.\mathrm{mL}^{-1}\right)$ for the studied populations of cyanobacteria $(\mathrm{C} 1, \mathrm{C} 2, \mathrm{C} 3, \mathrm{C} 4, \mathrm{O} 4(\mathrm{FL} 2))$ and picoeukaryotes at the maximum copper concentration toxic effect.

\begin{tabular}{lcc}
\hline Samples & $0 \mathrm{~h}$ & $72 \mathrm{~h}$ \\
\hline Cyanobacteria & $12333 \pm 2840$ & $11572 \pm 260$ \\
C1 & $1311 \pm 200$ & $1300 \pm 38$ \\
C2 & $34888 \pm 1033$ & $6288 \pm 300$ \\
C3 & $33575 \pm 14500$ & $119425 \pm 10400$ \\
C4 & $3091 \pm 194$ & $162 \pm 76$ \\
O4(FL2) & & \\
Picoeukaryotes & $4475 \pm 260$ & $1650 \pm 70$ \\
O1 & $10202 \pm 822$ & $8166 \pm 436$ \\
O2 & $5986 \pm 150$ & $5350 \pm 500$ \\
O3 & $4466 \pm 398$ & $1158 \pm 117$ \\
O4 & & \\
\hline
\end{tabular}

showed higher copper concentrations $(0.98 \pm 0.1 \mu \mathrm{g}$ $\left.\mathrm{L}^{-1}\right)$ than oceanic seawater $\left(0.2 \pm 0.2 \mu \mathrm{g} \mathrm{\textrm {L } ^ { - 1 }}\right)$. In the case of measured nominal copper concentrations, small deviations were obtained, ranging from \pm 0.3 to $\pm 0.48 \mu \mathrm{g} \mathrm{L}^{-1}$, and copper adsorbed to glass was of a maximum of $6 \%$ at the highest copper exposure concentrations (9 and $18 \mu \mathrm{g} \mathrm{L}^{-1}$ ).

When the toxic effects of copper on the four coastal cyanobacteria populations were compared, populations $\mathrm{C} 1$ and $\mathrm{C} 2$ were the most tolerant, showing no apparent growth inhibition up to the highest copper concentration exposure of $9 \mu \mathrm{g} \mathrm{L} \mathrm{L}^{-1}$. It is important to note that these two samples differ from the other two in that they were collected from salt marshes, while the others were obtained from coastal seawaters in the open Mediterranean Sea. Figure 5 shows percentage of growth inhibition for the other two coastal samples when exposed to the copper studied concentrations. As can be seen, $\mathrm{C} 4$ shows a higher tolerance than $\mathrm{C} 3$, with $\mathrm{EC}_{50}$ values for $\mathrm{C} 4$ and $\mathrm{C} 3$ of $>9 \mu \mathrm{g} \mathrm{L}^{-1}$ and 1.4 $\mu \mathrm{g} \mathrm{L} \mathrm{L}^{-1}$, respectively. 


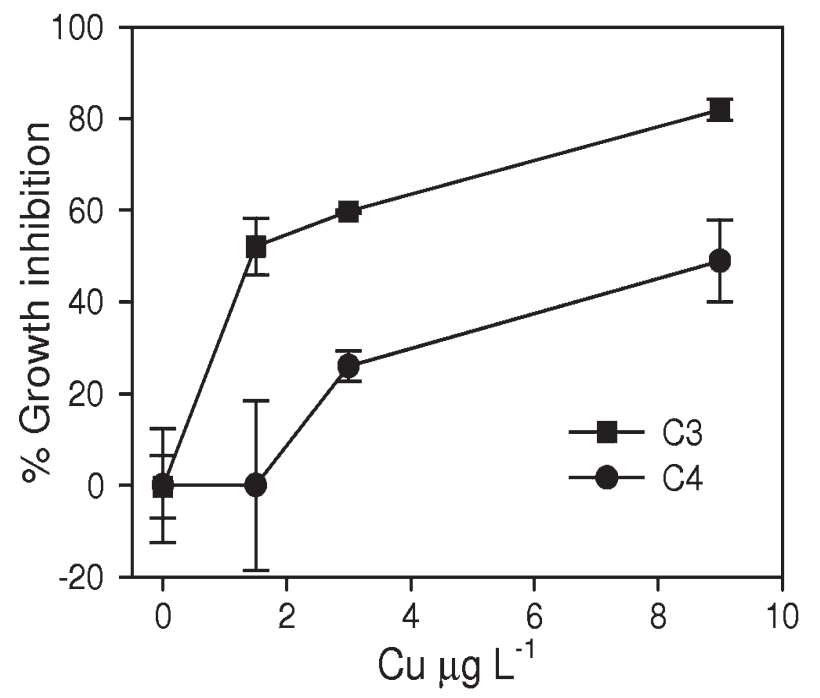

FIG. 5. - \% of growth inhibition of coastal populations when exposed to copper. Populations $\mathrm{C} 1$ and $\mathrm{C} 2$ showed no inhibition for this copper concentration range, so were not included in the figure.

From the other parameters obtained by flow cytometry (information of cellular size, chlorophyll $a$, and phycocyanin), no clear variations in the two most tolerant populations $(\mathrm{C} 1$ and $\mathrm{C} 2)$ were observed. However, in the case of cyanobacteria populations affected by the copper concentrations studied (C3 and $\mathrm{C} 4)$, as is shown in Figure 6, a similar tendency in signals for SSC, FL3 and FL4 was observed. The SSC signal showed a tendency to increase in size with the increase in copper concentration, but in the most sensitive case, $\mathrm{C} 3$, when inhibition growth values were close to $100 \%$, SSC values decrease in size to reach normal initial size values. For the other two signals FL3 and FL4 data showed a similar, but slighter pattern.
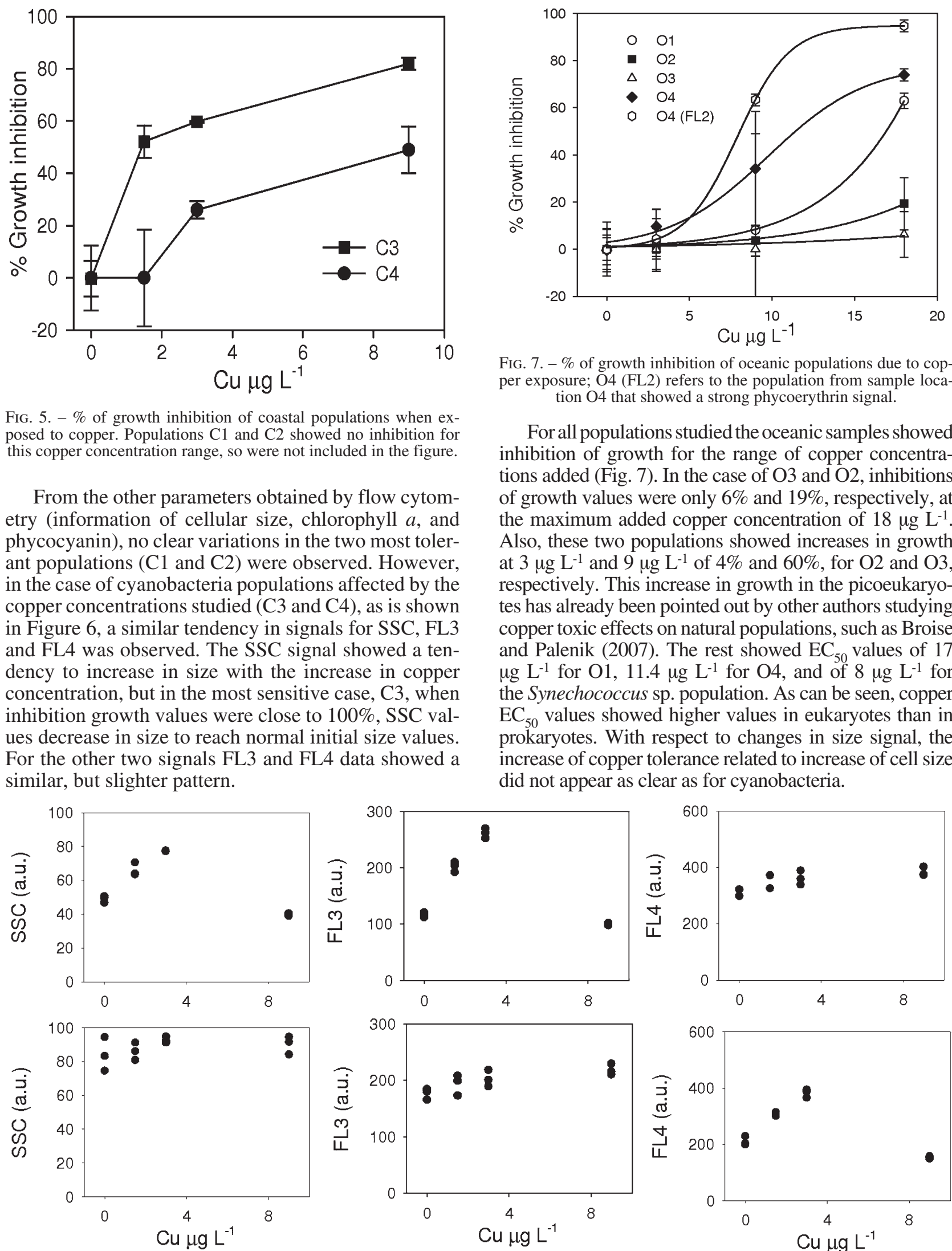

FIG. 7. $-\%$ of growth inhibition of oceanic populations due to copper exposure; O4 (FL2) refers to the population from sample location $\mathrm{O} 4$ that showed a strong phycoerythrin signal.

For all populations studied the oceanic samples showed inhibition of growth for the range of copper concentrations added (Fig. 7). In the case of $\mathrm{O} 3$ and $\mathrm{O} 2$, inhibitions of growth values were only $6 \%$ and $19 \%$, respectively, at the maximum added copper concentration of $18 \mu \mathrm{g} \mathrm{L} \mathrm{L}^{-1}$. Also, these two populations showed increases in growth at $3 \mu \mathrm{g} \mathrm{L}^{-1}$ and $9 \mu \mathrm{g} \mathrm{L}^{-1}$ of $4 \%$ and $60 \%$, for $\mathrm{O} 2$ and $\mathrm{O} 3$, respectively. This increase in growth in the picoeukaryotes has already been pointed out by other authors studying copper toxic effects on natural populations, such as Broise and Palenik (2007). The rest showed $\mathrm{EC}_{50}$ values of 17 $\mu \mathrm{g} \mathrm{L}{ }^{-1}$ for O1, $11.4 \mu \mathrm{g} \mathrm{L}^{-1}$ for $\mathrm{O} 4$, and of $8 \mu \mathrm{g} \mathrm{L}-1$ for the Synechococcus sp. population. As can be seen, copper $\mathrm{EC}_{50}$ values showed higher values in eukaryotes than in prokaryotes. With respect to changes in size signal, the increase of copper tolerance related to increase of cell size did not appear as clear as for cyanobacteria.

FIG. 6. - Data of size, chlorophyll $a$, and phycocyanin (in arbitrary units), for the two most sensitive coastal populations studied; top charts correspond to population $\mathrm{C} 3$ and bottom charts to population $\mathrm{C} 4$. 

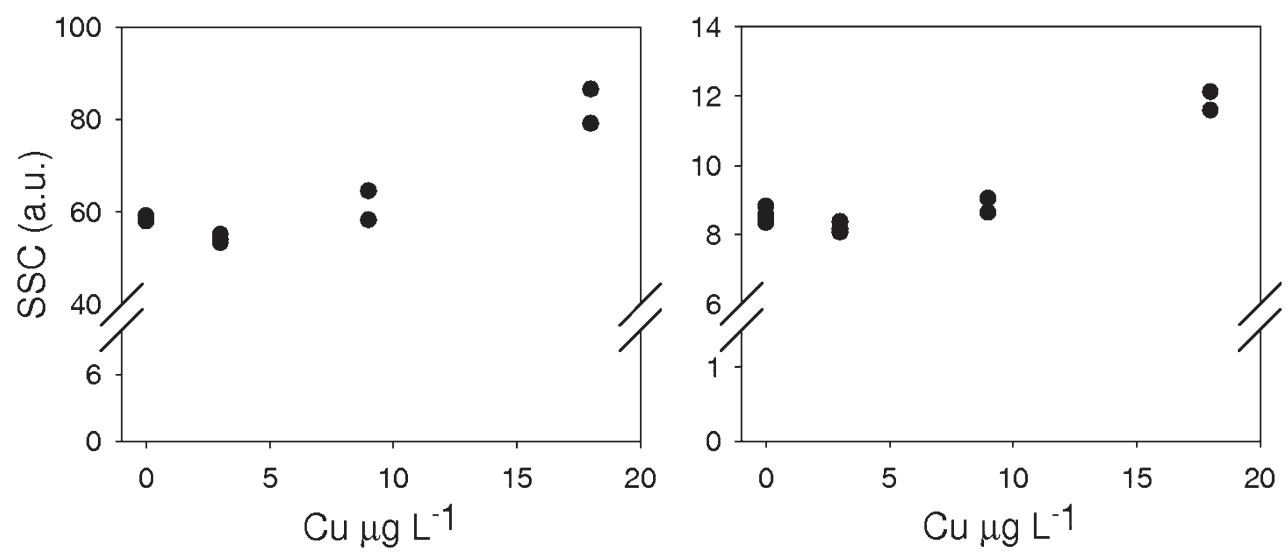

FIG. 8. - SSC arbitrary unit variations with increase in copper exposure for sample O4. The dot plot on the left corresponds to the picoeukaryote population and the one on the right to the prokaryote population with FL2.

Samples O1, O2, and O3 did not show great variations in the SSC and FL3 signals. The O4 eukaryotic population and Synechococcus sp. showed a clear exponential enhancement of SSC with an increase in copper concentration, as is observed in Figure 8. These two populations also showed variations in the FL3 signals, but this time each showed a different response: while the picoeukaryotic population showed an increase in chlorophyll $a$ signal at a copper concentration range of 9 to18 $\mu \mathrm{g} \mathrm{L}{ }^{-1}$, Synechococcus $\mathrm{sp}$. showed a decrease at the same range. Also, in the case of Synechococcus sp. population, FL2 data showed similar variations to FL3 data. This high correlation between FL3 and FL2 signals has already been reported by Broise and Palenik (2007).

When all experimental data from all different geographic locations sites are arranged, as is shown in Figure 9, there appears to be an exponential increase in tolerance related to size, which had already been clearly established in the coastal samples.

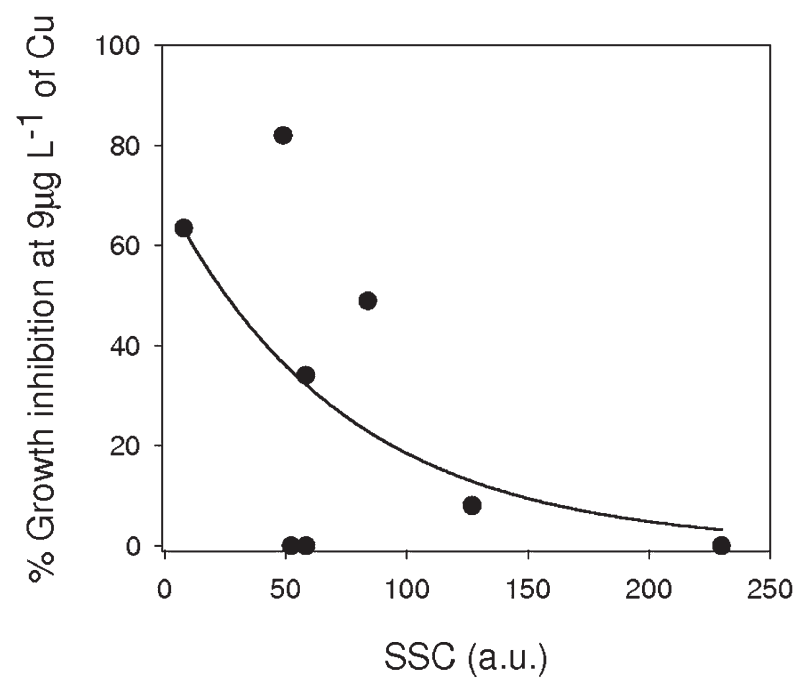

FIG. 9. - Scatter plot of size relationship with microalgae copper tolerance, expressed as the different $\%$ of growth inhibition at the copper exposure concentration of $9 \mu \mathrm{g} \mathrm{L^{-1 }}$.

\section{DISCUSSION}

This study aims to provide some indication of how similar populations from different locations can act when toxic copper concentrations are added. Our results are consistent with previous studies describing cyanobacteria as a highly copper-sensitive phytoplankton group (Brand et al., 1986; Le Jeune et al., 2006; Broise and Palenik, 2007). However, further studies with a larger diversity of population groups and geographical locations should be made in order to establish clear, definitive conclusions.

Copper sensitivity of cyanobacteria populations in this study showed a clear relationship with size, chlorophyll $a$ and phycocyanin signals: larger cells, with higher chlorophyll $a$ and phycocyanin average signals were the most tolerant, and as all these signals decreased a greater copper sensitivity appeared.

This marked copper sensitivity of cyanobacteria was reported by Brand et al. (1986) and Quigg et al. (2006). Several authors have tried to find an explanation for it. It is difficult to conclude whether differences in copper toxicity are associated with factors other than taxonomic differences, but this study aims to introduce other aspects that may influence copper tolerance.

Quigg et al. (2006) studied copper uptake kinetics and observed, in agreement with Brand et al. (1986), a high uptake rate of copper in cyanobacteria. Mann et al. (2002) established that a greater cell size of eukaryotes relative to prokaryotes may have provided an additional selective advantage against toxic metal accumulation in these algae. Lombardi and Viera (2000) and Lombardi et al. (2005) showed that extracellular polysaccharides produced by several freshwater cyanobacteria in growth phase acted as copper-complexing ligands. Levy et al. (2008) suggested that copper sensitivity and tolerance is not related to copper uptake rates but rather to detoxification processes.

To explain the differences in tolerance of populations, suggestions of influence of variations in the in situ environment have been made. For example, Waterbury et al. (1986) suggested that particular ma- 
rine habitats often contain a characteristic diversity of forms which may differ markedly from season to season and between different geographical locations, and Le Jeune et al. (2006) reported a seasonal sensitivity to copper stress in phytoplanktonic communities which were more sensitive to copper in spring than in summer or autumn. Sunda (1987) proposed that phytoplankton exhibit differential sensitivity to copper toxicity according to the regime to which they are adapted and Harrison et al. (1977) found that the communities from copper-exposed enclosures after 1 month had an $\mathrm{EC}_{50}$ value around one order of magnitude higher than the communities from the control enclosures.

In this study, in addition to the copper toxic effects on the different natural marine microalgae populations, because collected samples differed greatly with regard to their geographic position (from the Atlantic Ocean to the Mediterranean Sea), the influence of the geographic position on the toxic effect of copper was studied. The results showed clear tolerance differences between coastal and oceanic samples, suggesting that copper exposure is more likely in coastal populations than in oceanic populations. In the case of coastal populations, those belonging to east latitudes appeared to be more sensitive than those from the west: from east to west copper $\mathrm{EC}_{50}$ values were $1.4 \mu \mathrm{g} \mathrm{L} \mathrm{L}^{-1}, 9 \mu \mathrm{g}$ $\mathrm{L}^{-1}$, and $>9 \mu \mathrm{g} \mathrm{L}^{-1}$. It is important to note that these populations show great differences in size, showing from this copper tolerance-size relationship a clear increase in tolerance with cell size. On the other hand, for oceanic samples collected from different latitude locations, populations from latitudes close to $0^{\circ}(\mathrm{O} 3$ and O4) appear to be more tolerant than those situated at the extremes, especially those situated in the southern latitudes of the Atlantic Ocean. It could be that populations belonging to sites $\mathrm{O} 2$ and $\mathrm{O} 3$, closest to the South American coast where copper concentrations are higher (Günter, 1999), are more tolerant than populations situated in the middle of the Atlantic Ocean, such as $\mathrm{O} 4$, where total copper values are lower and therefore may be more sensitive to increased incorporation of copper. The same may happen in the case of the two most tolerant cyanobacteria populations, which unlike the other one, were collected from salt-marshes where water recirculation is scarce and high salinity values are reached by evaporation. Therefore, any possible contamination results in a higher concentration and tolerance to physical-chemical parameters differs from that of the other cyanobacteria obtained from the open Mediterranean Sea. Furthermore, Walle et al. (1993) stated that the input of pollutants into the Mediterranean Sea has a major impact because it is a semi-enclosed sea, so pollutants discharged in coastal areas are not sufficiently dispersed or diluted.

In short, we can conclude that data in this study demonstrate a frequent higher copper toxicity on cyanobacteria than on picoeukaryotes, showing copper toxic effects that can occur at such low concentrations as $1.4 \mu \mathrm{g} \mathrm{L}^{-1}$. These concentrations can easily be encountered in coastal areas due to ship anti-fouling paints and urban runoff (Broise and Palenik, 2007). Mann et al, (2002) found copper concentrations in the Sargasso Sea surface from $0.38 \mathrm{ng} \mathrm{L}^{-1}$ to values of $6.35 \mathrm{ng} \mathrm{L}^{-1}$ in polluted harbours. Satpathy et al. (2006) found copper concentrations of up to $44 \mu \mathrm{g} \mathrm{L}^{-1}$ on the Kalpakkam Coast, East India. On the other hand, the relationship between copper tolerance and geographical position of organisms is not sufficiently clear and a greater number of sample sites must be used in order to establish a clear tendency of tolerance with longitude-latitude distribution. Other factors, such as size, coinciding with a larger tolerance related to a larger cell size in this study, or a closer situation to the coast, may be more significant of the microalgae tolerance to a toxic compound.

It should also be considered that there is a great variety of environmental factors that are known to modify the toxicity of metals in seawater to a given test organism: $\mathrm{pH}$, presence of inorganic carbon and phosphorus, exchange reactions between suspended sediments and seawater (Hollibaugh et al., 1980), nutrients, temperature, light and wind (Broise and Palenik, 2007). Hence, much work still has to be done in the study of toxic effects on natural marine microalgae.

\section{ACKNOWLEDGEMENTS}

This work has been supported by the Spanish CICYT (Spanish Commission for Research and Development) in the contract of the project PETRI 95-0971. We thank Carmen Lama and Maria del Mar Fernandez for technical support, and E. Marañón for facilitating the participation in the TYNITROP oceanographic campaign for collecting oceanic samples.

\section{REFERENCES}

Brand, L.E., W.G. Sunda and R.R.L. Guillard. - 1986. Reduction of marine phytoplankton reproduction rates by copper and cadmium. J. Exp. Mar. Biol. Ecol., 96: 225-250.

Broise, D. and B. Palenik. - 2007. Immersed in situ microcosms: A tool for the assessment of pollution impact on phytoplankton. $J$. Exp. Mar. Biol. Ecol., 341: 274-281.

Bruland, K.W. and R.P. Franks. - 1983. Mn, Ni, Cu, Zn and Cd in the western north Atlantic. In: C.S. Wong, E. Boyle, K.W. Bruland, J.D. Burton and E.D. Goldberg (eds.), Trace metals in seawater. NATO Conference Ser. 4, V. 9. Plenum.

Coale, K.H. - 1991. Effects of iron, manganese, copper and zinc enrichments on productivity and biomass in the subartic Pacific. Limnol. Oceanogr., 36: 1851-1864.

Debelius, B., J.M. Forja, T.A. DelValls and L.M. Lubián. - 2009. Toxicity of Copper in natural marine picoplankton populations. Ecotoxicology, 18: 1095-1103.

Günter, J. - 1999. COPPER. Its Trade, Manufacture, Use, and Environmental Status. Ed. Konrad J.A. Kundig, ASM International.

Gustavson, K. and S-A Wänberg. - 1995. Tolerance and succession in microalgae communities exposed to copper and atrazine. Aquat. Toxicol., 32: 283-302.

Harrison, W.G., R.W. Eppley and E.H. Renger. - 1977. Phytoplankton nitrogen metabolism, nitrogen budgets and observations on copper toxicity: controlled ecosystem pollution experiment. Bull. Mar. Sci., 27: 44-57.

Hollibaugh, J.T., D.L.R Seibert and W.H. Thomas. - 1980. A comparison of the acute toxicities of ten heavy metals to phyto- 
plankton from Saanich Inlet, B.C., Canada. Estuar. Coast. Mar. Sci., 10: 93-105.

Hong, S., J.P. Candelone, C.C. Patterson and C.F. Bourton. - 1996. History of ancient copper smelting pollution during Roman and Medieval times recorded in Greenland ice. Science, 272: 246-249.

Janseen, C.R., D.G. Heijerick, K.A.C. De Schamphelaere and H.E. Allen. - 2003. Environmental risk assessment of metals: tools for incorporating bioavailability. Environ. Int., 28: 793-800.

Le Jeune, A-H., M. Charpin, V. Deluchat, J-F. Briand, J-F. Lenain, M. Baudu and C. Amblard. - 2006. Effect of copper sulphate treatment on natural phytoplankton communities. Aquat. Toxicol., 80: 267-280.

Levy, J.L., B.M. Angel, J.L. Stauber, W.L. Poon, S.L. Simpson, S.H. Cheng and D.F. Jolley. - 2008. Uptake and internalisation of copper by three marine microalgae: Comparison of copper sensitive and copper tolerant species. Aquat. Toxicol., 89: 82-93.

Lombardi, A.T. and A.A.H. Viera. - 2000. Copper complexation by Cyanophyceae and Clorophyceae exudates. Phycologia, 39: $118-125$.

Lombardi, A.T., T.M.R. Hidalgo and A.A.H. Viera. - 2005. Copper complexing properties of dissolved organic materials exuded by the freshwater microalgae Scenedasmus acuminatus (Chlorophyceae). Chemosphere, 60: 453-459.

Mann, E, N. Ahlgren, J.W. Moffett and S.W. Crisholm. - 2002. Copper toxicity and cyanobacteria ecology in the Sargasso Sea. Limnol. Oceanogr., 47: 976-988.

Moreno-Garrido, I. - 1997. Toxicidad y acumulación de metales pesados en microalgas marinas usadas en acuicultura. $\mathrm{Ph} . \mathrm{D}$. thesis, Univ. Cádiz.

Quigg, A., J.R. Reinfelder and N.S Fisher. - 2006. Copper uptake kinetics in diverse marine phytoplankton. Limnol. Oceanogr., 51: 893-899.

Satpathy, K.K, U. Natesan, S. Kalaivan, A.K Mohanty, M. Rajan and B. Raj. - 2006. Total dissolved copper concentrations in coastal waters of Kalpakkam. Curr. Sci. India, 91: 1008-1010.

Sobrino, C, O. Montero and L.M. Lubián. - 2005. Effect of UV-A and UV-B on diel patterns of growth and metabolic activity in Nannochloris atomus cultures assessed by flow cytometry. Mar. Ecol. Prog. Ser., 293: 29-35.

Stauber, J.L. and C.M. Davies - 2000. Use and limitations of microbial bioassays for assessing copper bioavailability in the aquatic environment. Environm. Rev., 8: 255-301.

Sunda, W.G. - 1987. Neritic-oceanic trends in trace-metal toxicity to phytoplankton communities. In: J.M. Capuzzo (ed.), Oceanic processes in marine pollution, pp. 19-29. Krieger.

Sunda, W.G. and R.L Guillard. - 1976. The relation between cupric ion activity and the toxicity of copper in phytoplankton. J. Mar. Res., 34: 511-529.

Thomas, W.H. and D.L.R Seibert. - 1977. Effects of copper on the dominance and the diversity of algae: controlled ecosystem pollution experiment. Bull. Mar. Sci., 27: 23-33.

Walle, F.B., M. Nikolopoulou-Tamvakli and W.J. Heinen. - 1993. European Community Countries (Environment and Assessment): Environment Condition of the Mediterranean Sea. Springer.

Waterbury, J., S. Watson, F. Valois and D. Franks. - 1986. Biological and ecological characterization of the marine unicellular cyanobacterium Synechococcus. In: T. Pratt and W.K.W. Li (eds.), Photosynthetic picoplankton. Can. Bull. Fish. Aquat. Sci., 214: 71-120.

Wolter, K., U. Rabsch, P. Krischker and A.G. Davies. - 1984. Influence of low concentrations of cadmium, copper and zinc on phytoplankton of natural water samples. Mar. Ecol., 19: 167-173.

Received November 11, 2008. Accepted July 30, 2010.

Published online November 13, 2010. 